\title{
A CONSTRUÇÃO DA IDENTIDADE ÉTNICA NA ESCOLA O PAPEL DOS PROFESSORES DE LÍNGUAS ${ }^{\mathrm{i}}$
}

\author{
Adriana Dalla Vecchia é professora da Faculdade Campo Real e mestranda do Programa Linguagem, Identidade e Subjetividade da \\ Universidade Estadual de Ponta Grossa/UEPG. \\ E-mail: adrianarevisao@gmail.com \\ Letícia Fraga é docente da Universidade Estadual de Ponta Grossa/UEPG, orientadora deste trabalho. \\ E-mail: leticiafraga@gmail.com
}

RESUMO

Neste texto discutimos como a Colônia Entre Rios (Guarapuava/PR) organiza-se políticolinguisticamente, enfatizando as estratégias de manutenção das decisões adotadas pelo grupo.
ABSTRACT:

In this paper we discuss how the Colonia Entre Rios (Guarapuava/PR) is organized as politicallinguistically and we will point the maintenance of strategies decisions adopted by these groups.

Falar é, em si, uma prática política.

Orlandi, 1988

\section{1) Introdução}

Sendo o Brasil um país multilíngue conforme nos demonstra Cavalcanti (1999), podemos dizer que o número de pesquisas que visam observar e deflagrar ambientes bi/multilíngues tem sido cada vez maior justamente no sentido de discutir essa diversidade. Existe, não só no Brasil, uma imagem ilusória de povos exclusivamente monolíngues, uma vez que o monolinguismo, desde os primórdios dos estudos linguísticos, foi - e em vários segmentos ainda é - a base para qualquer estudo (Cavalcanti, 1999, p. 388). Por essa razão, consideramos importante conhecer a realidade linguístico-cultural brasileira para que o mito da língua e cultura única possa ser superado.

Os grupos linguísticos que vivem em contextos complexos como esses, como é o caso das colônias de imigração, não são homogêneos e se compõem de pessoas que se percebem diferentes em relação aos demais indivíduos de fora da colônia pelo fato de falarem duas ou mais línguas, o que muitas vezes gera conflitos internos, não só de ordem linguística, mas também cultural e social. Nesses contextos, determinados usos linguísticos, em geral, levam ao desenvolvimento de preconceitos que, por sua vez, podem desencadear conflitos identitários nos indivíduos pertencentes aos diferentes subgrupos que se formam dentro do mesmo espaço.

Partindo dessa pressuposição, neste texto discutiremos as políticas linguísticas que configuram o Brasil conforme a descrição acima e, diante dessa caracterização, problematizaremos a forma como as comunidades étnicas multilíngues, mais 
especificamente a comunidade de imigração alemã-suábia denominada Colônia Entre Rios (Guarapuava/PR), organizam-se político-linguisticamente conforme o que julgam mais adequado, segundo parâmetros próprios, considerando que as crenças dessa comunidade em relação ao uso de línguas determinam as políticas linguísticas adotadas, enfatizando como a visão e as crenças dos professores de línguas influenciam nesse processo. Além disso, serão enfatizadas as estratégias de manutenção dessas decisões adotadas pelo grupo linguístico Suábios do Danúbio na Colônia Entre Rios, demonstrando que essa convivência gera um uso pouco equilibrado das línguas postas em contato, afinal é muito comum que haja, dentro da comunidade, um desequilíbrio entre as línguas em termos de prestígio/desprestígio em razão de fatores históricos.

\section{2) Breve histórico da Colônia de Imigração Entre-Rios- Guarapuava/PR}

A colônia Entre-Rios teve sua fundação mais tardia, a partir de 1950, e tem semelhanças com outras colônias de imigração alemã, mas é única justamente pela forma como os imigrantes chegaram ao Brasil e pelo modo como tem se expandido e se desenvolvido desde os primeiros dias de existência até a atualidade.

Os habitantes da região de Entre Rios são também identificados como Suábios do Danúbio, denominação cunhada em 1922 que designa grupos populacionais de etnia alemã, do antigo Império Austro-Húngaro, que abrigava povos oriundos de diferentes províncias do Reino Alemão e não apenas da Suábia (Elfes, 1971). O grupo que desembarcou no Paraná, deparou-se, desde sua chegada, com uma política de nacionalização do ensino que atingia diretamente o direito dos imigrantes de falarem a(s) língua(s) de seus países de origem (Oliveira, 2009a/2009b).

Essa política havia se instaurado no país desde o estabelecimento do Estado Republicano e previa uma homogeneização cultural e linguística em prol da criação de uma identidade nacional, ou seja, as variedades de línguas, as línguas autóctones e alóctones foram silenciadas no ambiente nacional (Payer, 1999).

Desde a chegada dos Suábios na região de Guarapuava, houve uma preocupação do grupo com a educação das crianças. Então, em princípio, havia pequenas escolas estaduais em cada uma das comunidades. No entanto, em 1968, a Cooperativa Agrária Mista de Entre Rios fundou a Associação de Educação Agrícola Entre Rios que "assumiu a coordenação e a centralização do sistema educacional e cultural em Entre Rios". Foi, então, que o

Colégio Imperatriz Dona Leopoldina, situado à Avenida Michael Moor, ${ }^{\circ}$ 2097, em Colônia Vitória, Distrito de Entre Rios, Município de Guarapuava, surgiu para atender às necessidades educacionais dos imigrantes Suábios e é mantido pela Associação de Educação Agrícola Entre Rios. (Colégio Imperatriz)

A gestão da instituição, segundo seu histórico disponível no site do Colégio, é democrática e compartilhada, sendo a escola um espaço criado "para atender a 
comunidade e todas as mudanças, ações e projetos são desenvolvidos em consonância com a Entidade Mantenedora e a comunidade a qual pertence" (Colégio Imperatriz).

Por essas poucas características salientadas, já podemos observar que a instituição nasceu com o intuito de resistir à assimilação cultural, mantendo a língua e a cultura dos Suábios. Por outro lado, é bastante complexa essa questão, pois, de acordo com as informações dadas pela equipe pedagógica, a variedade de alemão falado pelos imigrantes e seus descendentes não é trabalhado em sala de aula, em vez deste, priorizase o alemão clássico, idioma que as crianças, ao chegarem à escola, desconhecem tanto quanto o português. Abordaremos essas questões com mais detalhamento nos tópicos seguintes.

\section{3) Políticas e Planejamentos Linguísticos}

Antes de qualquer discussão a respeito do tema, é fundamental que se compreendam os conceitos que amparam este trabalho. Abordamos aqui a noção de políticas linguísticas segundo o ponto de vista de Calvet (2007), que trata do surgimento e consolidação dos conceitos de política e de planejamento linguísticos, buscando não somente descrever cientificamente situações multilíngues diversas, como também orientar formas de intervenção por meio de determinados instrumentos de política e planificação linguística.

Os termos que organizam as discussões de Calvet (2007) surgiram pela primeira vez em um trabalho de Einar Haugen, de 1959, em que este discutia os problemas linguísticos enfrentados pela Noruega, problemas esses relacionados à ação interventora do Estado sobre as línguas faladas no país em prol de uma língua nacional. Em geral, os primeiros trabalhos e considerações nessa área tinham a preocupação de observar a ação do Estado sobre as línguas em uso, desconsiderando a forma como as ocorrências linguísticas se organizam dia a dia. Nesse sentido, os teóricos estavam mais preocupados com a implementação de políticas do que com seu desenvolvimento, pois enfatizavam a ação do Estado, sem questionar o poder que levava à intervenção. Calvet (2007) justifica essa escolha teórica pelo fato de os problemas relacionados ao plurilinguismo estarem em um momento de deflagração, ou seja, o período abarcou processos de descolonização e a questão das línguas (étnicas, oficiais, nacionais etc.) estava ligada ao reforço e manutenção do nacionalismo e à situação identitária da antiga colônia.

Outra característica que determinou o pensamento teórico da época foi o fato de os teóricos não fazerem parte das comunidades estudadas, de modo que não conseguiam desenvolver/propor uma política linguística que levasse em consideração o que representavam, para os falantes, as línguas de seu país; apenas analisavam o que percebiam, do seu ponto de vista, completamente desprovido de envolvimento afetivo. Conforme Calvet (2007), pensar política e planejamento linguísticos refere-se à "emergência de um conceito [...] que implica ao mesmo tempo uma abordagem científica das situações sociolinguísticas, a elaboração de um tipo de intervenção sobre 
essas situações e os meios para fazer essa intervenção" (Calvet, 2007, p. 19). Nessa perspectiva, sem as considerações teóricas, não há como intervir em situações plurilíngues que "necessitam" de intervenção, digamos assim. Dito de outra forma, nem sempre há a necessidade de intervenção, mas há complexidade de interação entre pessoas que falam línguas ou variedades de língua diferentes. Nesse sentido, até que alguém observe a situação e nela encontre problema, as decisões de caráter linguístico se dão aparentemente de forma mais tranquila.

Enquanto as primeiras abordagens se voltavam para a intervenção na língua, ou seja, no que o autor chama de corpus, a política linguística, do ponto de vista de Calvet (2007), preocupa-se com a funcionalidade da língua, "a fim de que possa desempenhar o papel que se espera que ela desempenhe do ponto de vista do status" (Calvet, 2007, p. 59 , grifos nossos). No que se refere ao status, as línguas são vistas e classificadas segundo dois critérios: o uso que os falantes fazem destas línguas e o número absoluto destes. Quanto à classificação, as línguas podem ser minoritárias, majoritárias, oficiais, nacionais, veiculares, entre outras; tais denominações adjetivam a percepção da presença da língua pela comunidade, tanto do lugar que ela ocupa "realmente", quanto do espaço que ela preenche em nosso imaginário. Pensar em uma intervenção de status, portanto, pressupõe considerar que uma língua possa passar de veicular a oficial, por exemplo. Quanto a isso, Calvet (2007) afirma que "os Estados são levados às vezes a promover uma ou outra língua até então dominada ou, ao contrário, retirar de uma língua um status de que ela gozava, ou ainda fazer respeitar um equilíbrio entre todas as línguas, ou seja, administrar o status e as funções sociais das línguas em presença" (Calvet, 2007, p.117, grifos do autor).

Segundo Calvet (2007):

A intervenção humana na língua ou nas situações linguísticas não é novidade: sempre houve indivíduos tentando legislar, ditar o uso correto ou intervir na forma da língua. De igual modo, o poder político sempre privilegiou essa ou aquela língua, escolhendo governar o Estado numa língua ou mesmo impor a língua de uma minoria (Calvet, 2007, p. 11).

A partir da Reforma Pombalina, as intervenções do Estado sobre as línguas no Brasil, por exemplo, demonstram o estabelecimento do uso de uma língua - o português - em detrimento de todas as outras existentes no país (Matos e Silva, 2004). Quando oficializado como língua do Estado, o português não era a língua da maioria em relação às outras também presentes no território brasileiro (Oliveira, 2009a). Foi o início de uma política em prol do monolinguismo em português que acabou efetivando-se especialmente pelo discurso da escola e da mídia brasileiras (Cavalcanti, 1999) que não reconhecem outras ocorrências linguísticas como línguas, política também entendida como glotocida no sentido de que apagou e apaga línguas minoritárias/minoritarizadas a ponto de muitas destas se perderem e morrerem (Matos e Silva, 2004).

Atitudes como essa são o que Calvet (2007) vem chamando de políticas linguísticas, ou seja, o conjunto "das grandes decisões referentes às relações entre as 
línguas e a sociedade" (Calvet, 2007, p. 11). Esse conjunto de escolhas é inseparável de sua implementação, o planejamento linguístico. A elaboração de uma Política Linguística pode se dar sem a intervenção do Estado, isto é, a princípio qualquer grupo minimamente organizado pode pensar sobre o processo ou decidir qual(is) língua(s) terá(ão) espaço em sua comunidade. A questão que se impõe é quanto ao planejamento, este em geral é realizado pelo Estado, o único que tem o poder e os meios de "pôr em prática suas escolhas políticas" (Calvet, 2002, p. 146). Isso não quer dizer, no entanto, que não haja políticas que não abranjam entidades menores que o Estado ou que transcendam fronteiras (francofonia, lusofonia entre outras), como afirma o próprio Calvet (2007, 2002).

Em situações linguisticamente complexas como as colônias de imigração, as comunidades indígenas e de fronteira, em que o próprio grupo linguístico resolve a complexidade da convivência entre os falantes de línguas diferentes dentro do mesmo ambiente, há uma política linguística que é válida apenas dentro daquele local, mas que se configura considerando o que é vigente fora dela. A esse processo Calvet (2007) dá o nome de gestão in vivo, pois é uma decisão que provém da prática social, ou seja, "refere-se ao modo como as pessoas resolvem os problemas de comunicação com que se confrontam cotidianamente". Essa gestão tanto pode resultar na adoção de uma língua já existente - veicular ou não - alterando seu status, como o caso salientado acima, quanto resultar em "línguas aproximativas", os pidgins; ambas as possibilidades, criação ou refuncionalização das línguas, não tem a ver com uma decisão oficial (Calvet, 2007, p. 69).

Quando a intervenção é pensada pelo Estado sem tomar como base a gestão in vivo, a decisão acerca dos usos linguísticos no ambiente plurilíngue é oficial. Esse é o caso de uma gestão in vitro: "em seus laboratórios, linguistas analisam as situações e as línguas, as descrevem, levantam hipóteses sobre o futuro das situações linguísticas, propostas para solucionar os problemas e, em seguida, os políticos estudam essas hipóteses e propostas, fazem escolhas, as aplicam" (Calvet, 2007, p. 70). Como se observa no caso descrito acima, a gestão in vivo chocou-se com a in vitro, quando houve, no Brasil, a nacionalização do ensino e o português como língua oficial invadiu as escolas da colônia, indo de encontro aos sentimentos linguísticos dos falantes. $\mathrm{O}$ ideal, segundo Calvet (2007), é que as duas gestões coincidam, ou seja, que a decisão in vitro reflita alterações que já se processaram in vivo.

Ao final de sua exposição e reflexão, Calvet (2007) propõe uma questão bastante pertinente para se pensar: "em que medida o homem pode intervir na língua ou sobre as línguas?" (Calvet, 2007, p. 160). Poder-se-ia ir além, questionando também como poderia haver uma intervenção sem necessariamente acontecer uma dominação social via dominação linguística. Diante desses questionamentos, percebe-se que mesmo a gestão in vivo gera dominação, ou seja, apesar de a comunidade estabelecer políticas linguísticas que orientam e instituem o uso das línguas em ambientes multilíngues, dificilmente o uso das diferentes línguas será equilibrado, sem que uma ou outra língua se sobressaia, assumindo maior prestígio sobre as outras. 


\section{4) Políticas linguísticas e a construção da identidade dos Suábios do Danúbios}

Nesse sentido, é possível dizer que as comunidades que vivenciam outras realidades são minorias ou, de acordo com Cavalcanti (1999), minoritarizadas, pois podem usar variedades desprestigiadas do português ou outra língua em sua tradição oral diferente da língua oficial do Brasil, em ambos os casos são línguas estigmatizadas, reflexo, muitas vezes, do estigma que está sobre seus falantes. Essas minorias podem apresentar realidades bastante diversas, mas todas têm algo em comum: continuam invisíveis graças à política do monolinguismo em português. As comunidades podem ser monolíngues em suas línguas étnicas, bilíngues em língua étnica e língua portuguesa, bilíngue em variedade desprestigiada da língua étnica e variedade de prestígio da língua étnica ou serem multilíngues.

No caso da Colônia Entre Rios, pelo tempo de observação e pelas informações trazidas pelos participantes desta pesquisa, podemos afirmar que é um ambiente multilíngue. Caracteriza-se dessa forma porque em seu interior circulam pelo menos três línguas distintas, além das suas variedades: a língua portuguesa, o Schwowisch e o Hochdeutsch. Nem todos os habitantes são multilíngues. Grande parte dos descendentes de Suábios falantes de Schwowisch escolarizados - especialmente no Colégio Imperatriz - é multilíngue. Existem os que não aprenderam o Schwowisch em casa, sendo falantes apenas de português e, nesse caso, ao ingressarem no Colégio Imperatriz a maioria torna-se bilíngue português (e suas variedades)/Hochdeutsch.

No que se refere aos alunos do Ensino Fundamental II, de $7^{\circ}$ a $9^{\circ}$ anos, há uma incidência grande de falantes nativos de Schwowisch. Pudemos observar isso por meio da aplicação do questionário fechado composto por seis perguntas nas quais os alunos manifestaram-se sobre as línguas que aprenderam em casa, as que usam em família e na escola com colegas e professores de língua alemã. Dos 59 alunos que responderam ao questionário, 35\% declararam ter aprendido em casa o Schwowisch, língua que ainda falam entre os familiares conforme demonstram os gráficos abaixo. 


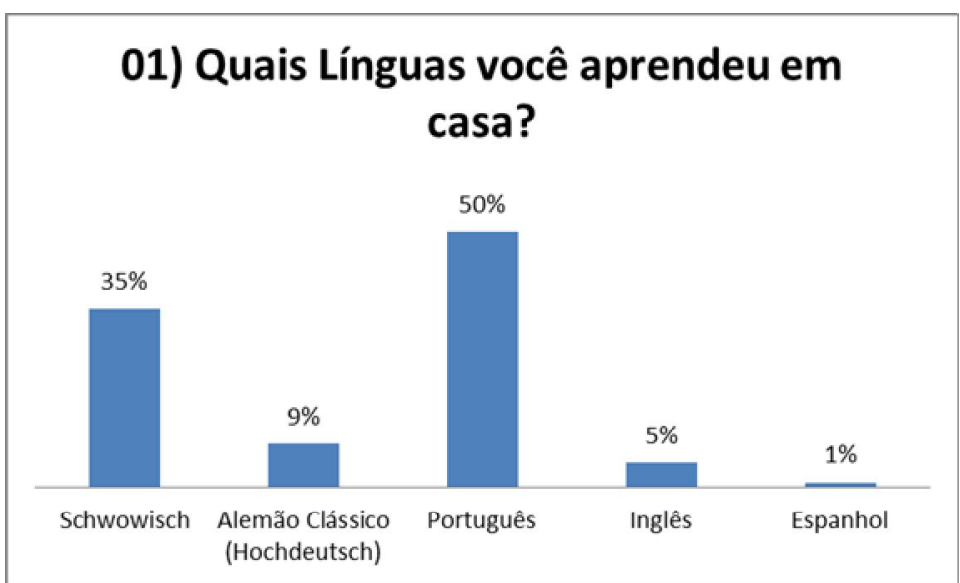

Gráfico 1: Demonstrativo das línguas aprendidas pelos alunos em casa.

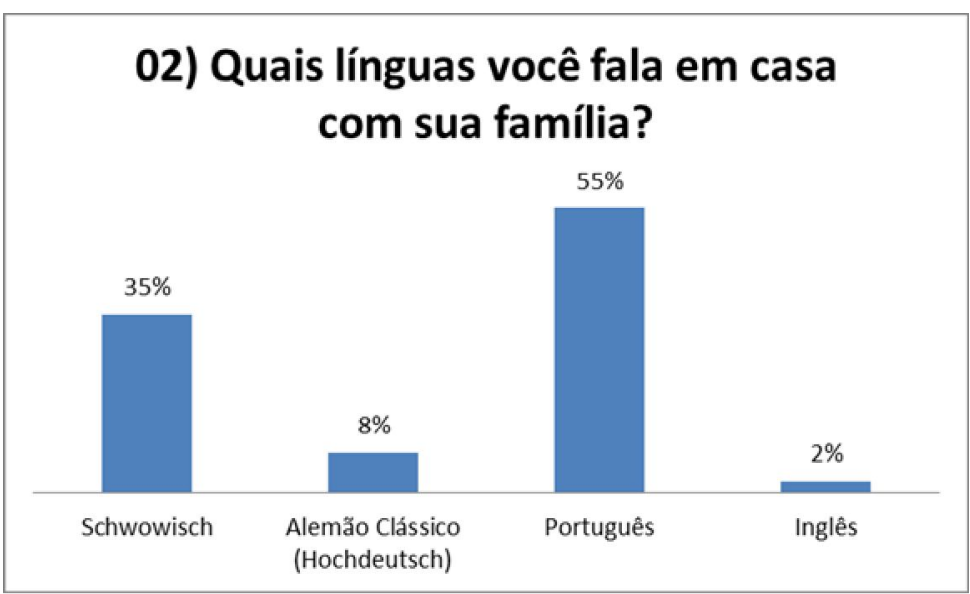

Gráfico 2: Demonstrativo das línguas faladas em ambiente familiar pelos alunos.

Observamos ainda que $100 \%$ dos alunos entrevistados se declararam falantes de português e de Hochdeutsch, o que configura, ao menos no ambiente escolar, uma situação de multilinguismo que envolve uma parcela desses alunos, já que 35\% deles também falam Schwowisch. Os participantes bilíngues em português/Hochdeutsch aqueles que aprenderam português em casa e Hochdeutsch no Colégio - julgam-se eficientes na interação em ambas as línguas da mesma forma que os multilíngues declaram-se eficientes nas três línguas que falam. Essas informações refletem as respostas dadas pelos alunos no questionário o que indica que é a forma como eles entendem o que é língua, o que é ser falante de uma ou mais línguas, ou seja, estamos trabalhando a partir das crenças desses adolescentes.

No entanto, conforme LF1 e LF5, essa situação de multilinguismo tende a acabar com o passar dos anos, pois a cada ano nota-se entre os ingressantes do Colégio menos falantes de Schwowisch.

a::li ((kindergarten $))$ é variado... ago::ra ultimamente a gente tem mais clientes [...] que falam só português em casa... antigamente... ahm... boa parte dos alunos... que eu falo 
agora ouvindo assim do que as professoras falam:: não falo por mim falo por elas né... porque elas sempre comentam né::... no/no jardim de infância que antigamente quase cem por cento dos alunos que entravam falavam o dialeto né... o Schwowisch deles... característico da colônia ali... e:: ago::ra não... boa parte dos alunos só falam português em casa.. Mudou a clientela de certa forma, né... (LF1).

na verdade não tem muitos mais descendentes de Suábios ou seja os Suábios não estão tendo muitos filho como antigamente... antigamente eram irmão de seis/sete hoje não... o casal tem no máximo dois filhos né... então eles chegam no jardim não tantos vêm outras crianças de fora... mas eles são alfabetizados juntos e conseguem acompanhar bem o alemão também (LF5).

Essa nova realidade da instituição, segundo o Diretor, obrigou o Colégio a alterar a configuração do ensino de alemão como se pode observar na transcrição abaixo referente à resposta ao questionamento sobre se o Colégio Imperatriz pode ser considerado uma instituição bilíngue.

Eu vejo o Colégio Imperatriz como uma escola com grande potencial na língua alemã mas que por uma necessidade de abertura não pode se considerar mais bilíngue porque eu digo isso? Nós tínhamos há bem pouco tempo atrás ou seja até o final do ano passado... um trabalho na educação infantil que era realizado no dialeto suábio [...] e depois acontecia a migração pra alfabetização em língua portuguesa e a partir do primeiro ano o aprendizado da língua alemã como língua estrangeira... em virtude do público que atualmente é de $60 / 70 \%$ de alunos que NÃO têm mais contato direto com a língua alemã em casa então se é dessa forma eu não consigo construir uma proposta [...] financeiramente e pedagogicamente que dê conta de um processo bilíngue... (Diretor).

Essas explicações evidenciam a consciência tanto da docente quanto do Diretor de que não só a escola, mas como a colônia como um todo pode migrar para uma situação de bilinguismo em português/Hochdeutsch, embora segundo alguns a realização do Hochdeutsch seja tão difícil quanto a do português padrão. Nesse sentido, pode haver suplantação do Schwowisch e em seu lugar outra variedade mais prestigiada, talvez mais próxima do que se entende por alemão Hochdeutsch, se colocará. Essa migração de situação pode indicar que a variedade local de alemão tem sofrido uma espécie de desvalorização por ser de tradição oral, sendo ensinada aos mais jovens apenas por meio da oralidade, e não ser reconhecida como língua.

Embora haja essa possibilidade, como bem observa LM1, existe por outro lado uma política que busca uma igualdade, no sentido de não só valorizar a língua portuguesa que já tem seu espaço demarcado por ser a língua oficial do Brasil, mas valorizar a língua desses indivíduos, mesmo que apenas em sua realização formal.

Claro que se dá uma ênfase maior à língua alemã visto que os Suábios aqui falam dialeto alemão e por isso se dá uma ênfase maior... essa ênfase significa mais aulas do que inglês do que espanhol... são cinco aulas na maioria das turmas... em algumas quatro aulas (LM1). 
Processos políticos como esse são também alvos da reflexão de Aquino (2009), para quem igualdade "é dar a todas as comunidades bilíngues um tratamento que valorize suas línguas maternas e que lhes possibilite a conservação da língua e da cultura local, seja em ambiente familiar, escolar, ou em qualquer situação social" (Aquino, 2009, p. 238).

No Colégio Imperatriz, parece haver uma compensação pelo definhamento do Schwowisch ao se enfatizar o Hochdeutsch, uma vez que já se entende que aquele é um processo inevitável, mas, apesar disso, há uma língua próxima que pode ser usada para transmissão de cultura, valores e com a qual há identificação da população imigrante e descendente.

Nesse sentido, são compreensíveis as escolhas linguísticas da instituição, pois é possível observar um cuidado em tratar dessas questões linguísticas de modo que atendesse as necessidades e desejos da população local. É o que Altenhofen (2004) destaca como necessário para as comunidades de imigração multilíngues, ou seja, segundo o autor, é fundamental que a educação leve em consideração a situação linguística da comunidade, observando suas possibilidades sociais e linguísticas.

Esse movimento, apesar de ser coerente com as necessidades da comunidade, acaba deixando o Schwowisch numa posição de inferioridade em relação ao Hochdeutsch. Quanto a esse tipo de ocorrência, Cavalcanti (1999) elenca dois fatores como causa em situações como essa, um dos quais é: “a) as línguas faladas não são (d)escritas e como tal não são reconhecidas" (Cavalcanti, 1999, p. 398); e, não sendo descritas, acabam não ocupando o espaço escolar, ficando restritas, muitas vezes, ao ambiente doméstico e como língua de cultura apenas.

O Schwowisch está na escola mais fortemente no Jardim de Infância, em que as crianças estão sendo iniciadas no estudo da língua alemã padrão e algumas também na língua portuguesa. A partir do primeiro ano do Ensino Fundamental II, inicia o trabalho do alemão como língua estrangeira e é então que essa variedade passa a ser retirada da sala de aula paulatinamente. Esse processo é mencionado pelos professores de língua alemã durante as entrevistas: todos demonstram que o Schwowisch está sempre presente no falar dos alunos, principalmente marcado na pronúncia de alguns sons que se diferenciam da forma como seria pronunciado na língua alemã padrão. Diante desse fato e percebendo esse processo, os professores afirmam corrigir os alunos para que falem menos Schwowisch em sala de aula. Segundo os docentes, deixam claro que, na escola, os alunos não podem utilizar essa língua, mas, em ambiente familiar, é perfeitamente possível continuar o uso. Os professores de português, embora em menor grau, também sentem essa presença, nesse caso na escrita de uma ou outra palavra. No entanto, é preciso, segundo os professores, corrigir. Vejamos como LF1 e LF2 se manifestam a respeito disso.

eu sinto algumas dificuldades nesses alunos que falam dialeto em casa até na minha aula né porque a nossa ordem... a da coordenação e da direção é vocês não falam dialeto... e eu nem tem como né porque eu não sei o dialeto deles né... mas quando eles 
chegam a mim também preciso ajudá-los corrigi-los pra que eles não acabem falando só o dialeto né... (LF1).

se o aluno não sabe nada... se ele começa do zero você consegue trabalhar melhor porque você trabalha melhor o vocabulário... [...] ele leva mais tempo/ele leva mais tempo ((para aprender)) a estrutura da frase... os que falam dialeto em casa têm mais facilidade disso mas ((para)) nós professores de língua estrangeira às vezes é mais fácil você ensinar um aluno que não sabe nada de alemão do que um aluno que vem com essa deficiência e fala tudo misturado... fala misturado o português fala misturado o alemão.. então você/ você tem mais dificuldade porque ele acha que ele sabe e na verdade não sabe (LF2).

Ainda é fundamental tomarmos conhecimento do que falam os professores de português a respeito do uso do Schwowisch em sala de aula. Segundo as professoras entrevistadas, esse uso não chega a atrapalhar o ensino de língua portuguesa, tendo em vista que os alunos têm um bom domínio do português. Vejamos como LF4 e LF5 se expressam a esse respeito:

Eu percebo ((dificuldade apresentado pelo falante de Schwowisch)) mais é na escrita mesmo mas é raramente... não é sempre que acontece... eles conseguem separa bem sabe... apesar de eles virem de casa já com essa influência né... é um ou outro só ((que apresenta dificuldade)) na grafia mesmo da palavra... tipo o $\mathrm{n}$ pelo m... coisinhas assim...acentuação muito.. eles acentuam muito conforme o som (LF4).

((alunos falantes de Schwowisch apresentam dificuldade em relação?)) à escrita... (LF5).

A partir desses depoimentos, é possível inferir que o Schwowisch, apesar de ser a língua utilizada no dia dia-a-dia dos Suábios do Danúbio, tem status de língua estigmatizada. O estigma que a acompanha tem três causas possíveis: a) a de não ser considerada língua pelo governo alemão; b) ser reflexo do uso que faziam os ascendentes europeus na época anterior à vinda ao Brasil - nesse caso, as demais variedades de língua alemã influenciaram umas às outras e o Schwowisch passou a se relacionar com o português; e c) por apresentar grande mescla com o português.

Pelo exposto, observamos que em não sendo reconhecido pelo governo alemão como língua, o Schwowisch não podia auxiliar na persecução do objetivo da escola de ter considerável número de aprovação junto aos testes. Estes se pautavam no Hochdeutsch, então o alemão clássico sempre foi a língua da escola, num primeiro momento estudado como língua materna e, de 2006, para cá como língua estrangeira. E esse objetivo é o que guia o ensino de alemão na instituição, sobretudo depois de 2006, quando houve uma grande reformulação na condução das atividades dessa área no Colégio Imperatriz.

Talvez por acreditarem que Hochdeutsch estava muito próximo do Schwowisch, até 2006, o Hochdeutsch era ensinado como língua materna na escola, conforme nos informa LF2 e complementam LM1 e LF1. 
eu assumi daí a coordenação da língua alemã em 2006 e nessa época nós fizemos uma:: reestruturação:: na área de alemão... desde o primeiro ano até o Ensino Médio... ((antes disso)) era ensinado o alemão porém eles usavam livros que se usava na Alemanha e quando nós viemos nós introduzimos [...] o ensino de língua alemã para estrangeiros porque a comunidade aqui.. os alunos em casa eles praticamente falam dialeto misturado então nós vimos uma grande deficiência na fala [...] e achamos melhor introduzir o alemão para estrangeiros pra que o aluno criasse uma base boa... com vocabulário bom que também fosse trabalhada a questão da audição da leitura da escrita e da fala de uma maneira [...] construtiva (LF2).

P: Como o senhor caracteriza o Colégio Imperatriz? Trata-se de uma escola bilíngue?

LM1: Já foi... nos primeiros anos aqui ensinava-se alemão e outras matérias em alemão também... hoje não... hoje a língua alemão é uma língua estrangeira como o inglês como o espanhol... (LM1)

antes de eu chegar... o colé::gio considerava o alemão Muttersprache que seria:: o alemão:: como [...] primeira língua assim... e era muito difícil era muito complicado pros alunos [...] chegavam os livros extremamente difíceis de entender e:: eles não conseguiam desenvolver o alemão deles:: e eles acabam falando mais dialeto do que o alemão e aí [...] uma professora implantou uma nova configuração pro alemão na escola seguindo esse método das provas das DSD ((Deutsches Sprachdiplom der Kultusministerkonferenz)) né... e a nova maneira de ensinar e de aprender alemão né... que é essa que/que agora a Europa... que você encontra na Europa inteira e:: também no Brasil é a nova:: configuração do alemão né... (LF1).

Como se observa na fala de LF1, a escolha do alemão como língua estrangeira passou a ser vinculada às provas DSD. Antes de 2006, os resultados do Colégio nesses exames eram insatisfatórios e depois da reestruturação da área de alemão os números começaram a melhorar. A respeito disso, LF2 contextualiza da seguinte forma:

existe um convênio com o governo da Alemanha com/com... [...] o que é a representatividade do governo alemão no exterior desde:: 1980 já.. praticamente... eles fazem essas provas tá.. só que nos últimos anos ahm:: a coordenação da língua alemã [...] no Brasil que vem fazer esses exames aqui em Entre Rios eles estavam muito insatisfeitos com os exames porque os alunos falavam mais dialeto e eles faziam uma mistura entre o dialeto e a língua alemã... língua alemã oficial.. o alemão oficial... então eles faziam uma mistura muito grande... eles tinham uma deficiência muito grande principalmente na fala e na escrita né... então nós tivemos assim... fomos praticamente obrigados a fazer essa reestruturação pra melhorar essas duas habilidades a fala e a escrita principalmente (LF2).

A partir de então, todo o trabalho em alemão passou a pautar-se nessas provas. Estas avaliam quatro habilidades: ler, escrever, falar e ouvir; as quais são contempladas nos materiais didáticos escolhidos, conforme os professores explicaram nas entrevistas. Os materiais são selecionados de acordo com as exigências das provas. Também as metodologias são adotadas a fim de darem suporte para o desenvolvimento das habilidades exigidas nas DSD, por essa razão as avaliações são montadas nos moldes desses testes.

A preparação para esses momentos de avaliação inicia ainda no jardim de infância, conforme explica LM1: 
Para se atingir o nível C1 quanto mais cedo se começar é melhor... não necessariamente no jardim de infância nem todas as escolas ((escolas conveniadas com o governo alemão como o Imperatriz)) iniciam no jardim de infância mas como aqui a escola dá um grande valor a esta língua... a língua deles daqui então começa ((o ensino da língua alemã)) já no jardim de infância (LM1).

O trabalho em prol de bons resultados é intenso durante toda a Educação Básica, indo além da sala de aula, ou seja, os professores desenvolvem projetos como concurso de leituras, levam os alunos para outros ambientes externos à sala de aula para conduzir atividades em que o uso da língua alemã seja necessário. Nesse sentido, há o desenvolvimento do que tanto o Diretor quanto LF2 (citações anteriores) chamam de metodologia interativa.

Os professores e também a direção declaram-se satisfeitos com os resultados obtidos nas provas DSD. Embora o número de candidatos por ano à prova $\mathrm{C} 1$ (que é o nível mais elevado) seja reduzido (foram sete no ano de 2011), o índice de aprovação é alto. Segundo LF1,

das provas que são mandadas pelo consulado alemão... pelo governo alemão né... sempre $95 \% \ldots 100 \% \ldots 85 \% \ldots 90 \%$... em torno disso, nunca abaixo disso... os alunos têm aprovado nas provas né... então a gente vai aprimorando aos poucos e vai melhorando.. tanto o papel do alemão na escola quanto o desempenho dos nossos alunos né... lá fora... porque pra:: Agrária... o:: alemão... a gente não pode esquecer que a nossa chefe o nosso chefão ali é a Agrária né... e a Agrária pede que os alunos saiam de lá ((Colégio)) sabendo falar... sabendo escrever alemão porque eles são uma empresa que fala alemão que/que tem contatos com a Alemanha né... então se os alunos saem de lá não sabendo falar o alemão... eles não têm chances na Agrária e não é isso... eles querem os filhos deles sabendo falar corretamente o alemão... sabendo escrever... sabendo se... ahm:.... interagir com uma pessoa alemã né... um alemão (LF1).

Ao serem questionados sobre a configuração da instituição, Diretor e professores declararam acreditar que o Colégio Imperatriz não pode ser considerado bilíngue, sobretudo, porque o currículo prevê o ensino da língua alemão como língua estrangeira, partindo do pressuposto de que hoje grande parte dos alunos ingressantes é monolíngue em português. Essa clientela impossibilita, a menos por hora, a implantação de um currículo bilíngue. Vejamos as explicações dos participantes:

Eu considero lá no kindergarten que a gente tem uma presença muito mais forte dos pequenos vindo de casa essa questão ((falar Schwowisch e português))... os demais que não falam alemão de certa forma vão incorporando um pouco a linguagem já tem uma característica... não diria que seja bilíngue mas é bem mais próxima... aqui ((Ensino Fundamental I, II e Ensino Médio)) eu considero a língua alemã como ensino de língua estrangeira [...] porque nós não trabalhamos tanto com a marca do dialeto na oralidade... no kindergarten tem muito mais presente a presença da oralidade do dialeto... nós aqui trabalhamos com a estrutura do alemão oficial como língua estrangeira para que eles 
possam ter um bom desempenho na fala e na escrita de acordo com o alemão oficial (LF4).

Nesse caso, a professora parece entender que seria uma instituição bilíngue se o alemão fosse ensinado como língua materna e fosse mantida a prosódia do Schwowisch conforme ocorre no jardim de infância.

LF1 demonstra que o currículo deveria ter outra configuração para que a instituição fosse considerada bilíngue, em que os professores das demais disciplinas também usassem, além do português, o alemão.

Eu acredito que está caminhando pra isso... né:: eu acho que ainda não pode ser considerado bilíngue porque tem:: muitas aulas que predomina o português né... eu acho que seria bilíngue se:: algumas matérias fossem trabalhadas em alemão também né ((não só as de língua alemã))... eu acho que aí seria bilíngue/eu caracterizo o colégio Imperatriz como escola ( ) que seria alemão para estrangeiros né (LF1).

Nessa mesma linha, segue LF2 como observamos em sua fala,

como escola bilíngue? Não... eu acredito que não porque uma escola bilíngue ela ensina também ahm:: a segunda língua... a estrangeira... em outras matérias por exemplo em matemática história geografia... eu conheço por exemplo o colégio suíço brasileiro e os alunos têm.. em algumas matérias... eles têm alemão... a língua alemã.. isso sim... eles também fazem o exame de proficiência diferente que o nosso... eles fazem que nem o nosso mas em outro sistema né... porque/porque eles têm eh:: também isso no inglês... esse diferencial... nós aqui temos alemão também música ((disciplina))... música em alemão e a língua alemã... outras matérias não... então eu não considero propriamente uma escola bilíngue mas eu vejo o alemão como língua estrangeira... eu acho que é isso que vai se caracterizar futuramente cada vez mais porque sempre vêm mais alunos de fora pra cá... pra você ter uma ideia no jardim hoje já existem grupo em que tem mais/mais alunos... mais crianças de família onde não se fala mais o alemão em casa... do que de famílias onde em casa é falado o dialeto... [...] então eu não vejo como bilíngue... (LF2).

Na continuidade dessa resposta, LF2 vai além e explica que para ser bilíngue, deveria haver outros objetivos, segundo ela,

Nós não temos hoje necessidade fazer Bilíngue assim sabe... porque [...] nós temos condições desde o jardim até o final do Ensino Médio preparar o aluno pra ele poder estudar na Alemanha né... porque com essa certificação que ele ganha aqui... ele poderia teoricamente estudar na Alemanha... ele está preparado... (LF2).

O Diretor parece concordar com essa visão ao enfatizar que a estrutura curricular toda deveria ser alterada e haver público para uma escola bilíngue.

P: futuramente o Colégio poderia voltar a ser uma instituição bilíngue?

Diretor: eu acho que poderia... eu acho que poderia porém... eu não conseguiria atingir todo o meu corpo discente com essa proposta... então em termos de organização em termos de estrutura eu precisaria ou nós precisaríamos eventualmente pensar dois segmentos... dois braços né... dentro de uma mesma escola e para isso infelizmente eu não tenho público suficiente... existe uma proposta muito interessante não sei se você 
conhece de escolas em São Paulo Rio de Janeiro... aqui no Paraná acho que não temos nenhuma ainda... são colégios que focam numa prova... na verdade numa terminalidade multicultural bilíngue baseadas no sistema francês $\mathrm{AB}$... já houve pensamento se o Colégio Imperatriz não poderia se associar a essa proposta porque dentro desse programa você trabalha com:: dois idiomas... aliás três... uma materna a língua portuguesa e dois estrangeiros seriam a língua alemã e a língua inglesa de forma muito aprofundada... então assim... poder? poderia... a questão hoje é mais... ela é dificultada em virtude do pouco público do que efetivamente de uma possibilidade... de uma proposta ou de capacitação docente por exemplo (DIRETOR).

Essa preocupação em demonstrar que a escola não é bilíngue no atual momento está bastante presente nos discursos, cada um se embasando naquilo que acredita ser uma instituição bilíngue. Nesse sentido, podemos caracterizar, contraditoriamente, o Colégio Imperatriz como monolíngue ou ao menos oficialmente bilíngue conforme o faz Cavalcanti (1999) ao falar sobre a educação em comunidades de imigração. Segundo a autora, "[a]s escolas são oficialmente monolíngues, mas, em comunidades bilíngues, é natural que haja trânsito entre uma e outra língua e é isso que se viu na prática". Nesse sentido, "[é] claro que há sempre o receio de o professor de não estar trabalhando de acordo com a Secretaria da Educação", além disso "há sempre uma afirmação sobre o português como sendo a única língua da escola" (Cavalcanti, 1999, p. 396-397).

\section{Conclusão}

A partir do exposto, podemos reafirmar a presença do Schwowisch como língua estigmatizada em relação ao Hochdeutsch, sendo esta a língua escolhida como pré-requisito para a ascensão profissional na colônia, ou seja, para retomar Calvet (2007), houve uma alteração no status das línguas. Além disso, observamos que as ocorrências in vivo têm sido suplantadas pelas decisões in vitro. Essa complexidade linguística e respectiva política de administração das línguas em contato na região dão suporte para que o ambiente se firme enquanto espaço bilíngue. Pelo exposto, notamos que o multilinguismo existente está em franco declínio e a atuação tanto da escola quanto da mantenedora, amparadas pelo governo alemão, colabora para esse processo.

Ressaltamos ainda que essa política adotada na colônia se esquiva da política nacional no sentido de que reforça o monolinguismo, pois o Colégio Imperatriz se configura enquanto monolíngue em português, mas que tem em sua grade curricular o alemão, o inglês e o espanhol como línguas estrangeiras, conferindo ênfase à língua alemã em função de os moradores da região terem ascendência suábia, etnia alemã. Conforme Cavalcanti (1999), a questão do monolinguismo é naturalizada, ou seja, tornada natural e reforçada mesmo nesses ambientes caracteristicamente multilíngues ou bilíngues. Nesse sentido, observamos que, apesar de o Colégio trabalhar com sujeitos monolíngues em Schwowisch e bilíngues em Schwowisch/português, contribuindo para agregar-lhes mais o Hochdeutsch e sujeitos monolíngues português, levando-os para 
uma situação de bilinguismo em português/Hochdeutsch, não se declara como instituição bilíngue ou multilíngue.

\section{Referências Bibliográficas}

ALTENHOFEN, C. V. Política lingüística, mitos e concepções lingüísticas em áreas bilíngües de imigrantes (alemães) no Sul do Brasil. Disponível em: http://www.iberoamericana.net/files/ejemplo_por.pdf

AQUINO, C. de. "Uma discussão acerca do bilinguismo e do preconceito linguístico em populações bilíngues no sul do Brasil". Revista Letrônica v. 2, n. 1, julho 2009, p. 231 -240 .

CALVET, Louis-Jean. Sociolinguística: uma introdução crítica. Tradução de Marcos Marcionilo. São Paulo: Parábola, 2002.

. As políticas linguísticas. Tradução de Isabel de oliveira Duarte, Jonas Tenfen e Marcos Bagno. São Paulo: Parábola Editorial; IPOL, 2007.

CAVALCANTI, M. C. "Estudos sobre educação bilíngue e escolarização em contextos de minorias linguísticas no Brasil”". Revista D.E.L.T.A., Vol. 15, n. ${ }^{\circ}$ especial, 1999 (385-417).

COLÉGIO IMPERATRIZ DONA LEOPOLDINA. Disponível em: http://www.colegioimperatriz.net.br/historico.asp Acesso em 17 de julho de 2011.

DIRETOR. Entrevista Direção [jun. 2012]. Entrevistadora: Adriana Dalla Vecchia. Guarapuava: Colégio Imperatriz, 2012.

ELFES, A. Suábios no Paraná. Curitiba, PR: [s. n], 1971.

LF1. Entrevista professora de alemão [out. 2011]. Entrevistadora: Adriana Dalla Vecchia. Guarapuava: Colégio Imperatriz, 2011.

LF2. Entrevista professora de alemão [out. 2011]. Entrevistadora: Adriana Dalla Vecchia. Guarapuava: Colégio Imperatriz, 2011.

LF4. Entrevista professora de português [abr., 2012]. Entrevistadora: Adriana Dalla Vecchia. Guarapuava: Colégio Imperatriz, 2012.

LF5. Entrevista professora de português [jun., 2012]. Entrevistadora: Adriana Dalla Vecchia. Guarapuava: Colégio Imperatriz, 2012.

LM1. Entrevista professor de alemão [jun. 2012]. Entrevistadora: Adriana Dalla Vecchia. Guarapuava: Colégio Imperatriz, 2012.

MATOS e SILVA, R. V. Ensaios para uma sócio-história do português brasileiro. São Paulo: Editorial, 2004. 
OLIVEIRA, G. M. Línguas como patrimônio imaterial. 2009a. Disponível em: http://www.ipol.org.br/ler.php?cod=281 Acesso: 16/02/2011.

"Brasileiro fala português: Monolinguismo e Preconceito Linguístico". 11 ed.

Revista Linguasagem. São Paulo: UFSCAR, 2009b. Disponível em: www.letras.ufscar.br/linguasagem Acesso em 11 de maio de 2012.

PAYER, M. O. Memória da Língua: imigração e nacionalidade. Tese de doutorado orientada por Eni Pucinelli Orlandi. Universidade Estadual de Campinas. Instituto de Estudos da Linguagem. Campinas, SP: [s. n], 1999.

STEIN, M. O oitavo dia: produção de sentidos identitários na Colônia Entre Rios-Pr. Guarapuava: UNICENTRO, 2011.

${ }^{\mathrm{i}}$ Versão de um texto originalmente publicado nos Anais do X Encontro do CELSUL - Círculo de Estudos Linguísticos do Sul/UNIOESTE - Cascavel/PR. 